\title{
Quinalphos Induced Alterations in the Levels of Ions and Whole Animal Oxygen Consumption of Freshwater Fish, Cyprinus Carpio (Linnaeus, 1758)
}

\section{Sameer Gopal Chebbi and Muniswamy David*}

Karnatak University's research laboratory, environmental and molecular toxicology division, Department of Zoology, Karnatak Science College, Dharwad-580001, Karnataka, India

\begin{abstract}
The fingerlings of Cyprinus carpio were exposed to the lethal concentration $(7.5 \mu \mathrm{g} / \mathrm{l})$ of quinalphos (Emulsified Concentrate 25 percent) for 1,2,3 and 4 days respectively to study the levels and whole animal oxygen consumption. Exposed fish showed a significant decrease in the whole animal oxygen consumption due to the respiratory distress as a consequence of the impairment of oxidative metabolism. The ionic content of $\mathrm{Na}^{+}, \mathrm{K}^{+}$and $\mathrm{Ca}^{2+}$ also decreased significantly in gill, liver and muscle tissue of exposed fish, signifying the altered cellular proliferation and deranged $\mathrm{Na}^{+}$, $\mathrm{K}^{+}$and $\mathrm{Ca}^{2+}$ ionic pump due to probable consequence of tissue damage.
\end{abstract}

Keywords: Ions; Toxicity; Gill; Liver; Muscle; Calcium; Sodium; Potassium; Quinalphos

\section{Introduction}

The use of insecticides is being increase in the recent years to control the pest in which only $1 \%$ of the pesticide applied hits the target pest while, the remaining $99 \%$ of the pesticide drifts into the environment contaminating soil, water and biota [1]. This poses a constant threat to the non-target organisms especially to fishes; because pesticides are know to alter their behaviour pattern, growth, nutritional value and physiology. One of the early symptoms of acute pesticide poisoning is failure of respiratory metabolism. Some pesticides decrease the oxygen uptake of fish. The rate of oxygen consumption can be used as a bio-detector in monitoring the physiological effects of pesticides and the oxygen consumption pattern will indicate the possible mapping of metabolic pathways influenced by the pesticide stress [2]. Freshwater fishes are hyperosmotic to their medium. They gain water osmotically and tend to loosed solute by diffusion. In the regulation of osmolarity of system sodium, potassium and calcium ions play a significant role to keep the hyperosmotic properties of these animals [3].

Quinalphos is one of the organophosphate insecticide extensively used in agriculture in our area. The Environment Centre of National Toxicology declared that, there are a dozen highly dangerous chemicals including quinalphos. Quinalphos is a hard insecticide, which has become a matter of concern because of its potentiality and hazardous effect. The fish Cyprinus carpio was selected as experimental model because of its wide availability in local tanks and ponds of our area. It is also serves as a cheap protein rich source of food for vast population of India.

Hence in the present study, an attempt has been made to determine the relation between tissue ion content and oxygen consumption in fish, Cyprinus carpio exposed to quinalphos for different exposure periods.

\section{Materials and Methods}

Cyprinus carpio weighing $5 \pm 2 \mathrm{~g}$ and measuring an average length of $5 \mathrm{~cm}$ were collected from the State Fisheries Department, Dharwad, Karnataka, India and kept in large cement tank previously treated with potassium permanganate to clean it from microbial infection if any. All the experimental fish were acclimated to laboratory conditions for 15 days with dechlorinated water whose physico-chemical character were analysed by following the APHA [4]. Organophosphate insecticide quinalphos (EC 25\%) was obtained from Nagarjuna Chemical Ltd. Hyderabad, Andra Pradesh, India. The $\mathrm{LC}_{50}$ value for $96 \mathrm{hr}$ was determined by following the Finney [5] method and was found to be $(7.5 \mu \mathrm{l} / \mathrm{l})$. The fish were exposed to lethal concentration for $1,2,3$, and 4 days.

Required quantity of pesticide quinalphos was added to the exposure container using variable micropipette. The oxygen consumption was measured for lethal concentration for $1,2,3$, and 4 days by following the method of Welsh and Smith [6] and the apparatus set up was the same as described by Saroja [7]. After the stipulated time gill, muscle and liver isolated and weighted. They were wet ashed in 50:50 (V/V) concentrated perchloric acid and nitric acid [8] for half an hour until the organs were evaporated at $100^{\circ} \mathrm{C}$ to $200^{\circ} \mathrm{C}$ temperature. The residue obtained was dissolved in glass-distilled water and made up to $10 \mathrm{ml}$. It was filtered through Whatman No.1 filter paper and appropriate dilutions were made prior to estimations. $\mathrm{Na}^{+}, \mathrm{K}^{+}$and $\mathrm{Ca}^{2+}$ were estimated with the help of Atomic Absorbance Spectrophotometer (GBC 932 plus) and the values expressed in $\mu \mathrm{g} / \mathrm{g}$ wet weight of the organ. The date were subjected to analysis of variance and the means were compared by Duncan's new multiple range test at $0.05 \%$ level [9] to draw the mean comparison among the results.

\section{Result}

The rate of whole animal oxygen consumption ( $\mathrm{ml}$ oxygen consumed per gram wet weight of fish per hour) of control and

${ }^{*}$ Corresponding author: Dr. Muniswamy David, Karnatak Science College Staff Quarters No. D-1, Udaya Hostel road, Dharwad, Karnataka, India, Tel: +919845709815; E-mail: chebbisameer_2007@rediffmail.com

Received August 05, 2010; Accepted September 14, 2010; Published September 14,2010

Citation: Chebbi SG, David M (2010) Quinalphos Induced Alterations in the Levels of lons and Whole Animal Oxygen Consumption of Freshwater Fish, Cyprinus Carpio (Linnaeus, 1758). J Veterinar Sci Technol 1:102. doi:10.4172/21577579.1000102

Copyright: (c) 2010 Chebbi SG, et al. This is an open-access article distributed under the terms of the Creative Commons Attribution License, which permits unrestricted use, distribution, and reproduction in any medium, provided the original author and source are credited. 
Citation: Chebbi SG, David M (2010) Quinalphos Induced Alterations in the Levels of lons and Whole Animal Oxygen Consumption of Freshwater Fish, Cyprinus Carpio (Linnaeus, 1758). J Veterinar Sci Technol 1:102. doi:10.4172/2157-7579.1000102

Page 2 of 4

quinalphos treated fishes are presented in (Table 1). However the data on the levels of sodium, potassium and calcium ions $(\mu \mathrm{g} / \mathrm{g}$ wet weight of the organ) of the freshwater fish Cyprinus carpio to lethal concentration presented in (Table 2, Table 3 and 4).

\section{Oxygen consumption}

The data indicates that, the fish exposed to lethal concentrations of quinalphos oxygen consumption was reduced about $28.36 \%$ on day one and reached maximum reduction of $72.28 \%$ on day 4 . The decrement was a sudden leap from day one to day two, from then it was gradual reduction up to day 4 (Table 1 ).

\section{Sodium}

In gill sodium ion shows a gradual decrease in lethal concentration from day 1 to day 4 ranging from $14.50 \%$ to $44.16 \%$. In muscle similar fluctuation with $9.17 \%$ to $42.20 \%$ from day 1 to day 4 and in liver followed by $7.35 \%$ to $34.75 \%$ from day 1 to day 4 (Table 2, Figure 1 ).

\section{Potassium}

The potassium ion content in gill exhibited gradual decrement from day 1 to 4 ranging from $9.17 \%$ to $25.22 \%$. In muscle a maximum decrease of about $32.33 \%$ observed on $4^{\text {th }}$ day of the exposure period. However in liver the steady decrease of about $9.16 \%$ to $26.16 \%$ from day 1 to day 4 (Table 3, Figure 2).

\section{Calcium}

The calcium ion content also exhibited a steady decrement at lethal concentration. In gill, muscle and liver the maximum decrease was $18.45 \%, 27.66 \%$ and $22.36 \%$ respectively on day was recorded (Table 4 , Figure 3). All the alterations were significant at $0.05 \%$ levels.

\section{Discussion}

Since most fish breathe in the water in which they live, changes in the chemical properties thereof may be reflected in the animal's

\begin{tabular}{|l|l|l|l|l|}
\hline \multirow{2}{*}{ Tissue } & \multirow{2}{*}{ Control } & \multicolumn{4}{|l|}{ Lethal Exposure Period in Days } \\
\cline { 3 - 5 } & & Day 1 & Day 2 & Day 3 \\
\hline Estimation & $0.5722 \mathrm{a}$ & $0.4099 \mathrm{~b}$ & $0.3827 \mathrm{c}$ & $0.2299 \mathrm{~d}$ \\
\hline SD \pm & 0.0003 & 0.0004 & 0.0003 & 0.0004 \\
\hline \% change & --- & -28.36 & -33.11 & -1586 \\
\hline
\end{tabular}

Data are means $\pm \mathrm{SD}(n=6)$ for an organ in a row followed by the same letter are not significantly different $(p<0.05)$ from each other according to Duncan's multiple range test.

Table 1: Whole animal oxygen consumption ( $\mathrm{ml} \mathrm{O}_{2}$ consumed/gm wet wt. of fish/h) of fish, Cyprinus carpio exposure to lethal concentration (7.5 $\left.\mu \mathrm{l} / \mathrm{l}\right)$ of quinalphos.

\begin{tabular}{|l|l|l|l|l|}
\hline \multirow{2}{*}{ Tissue } & \multirow{2}{*}{ Control } & \multicolumn{4}{l|}{ Lethal Exposure Period in Days } \\
\cline { 3 - 5 } & & Day 1 & Day 2 & Day 3 \\
\hline Gill & $0.5457 \mathrm{a}$ & $0.4684 \mathrm{~b}$ & $0.4240 \mathrm{c}$ & $0.3365 \mathrm{~d}$ \\
\hline SD \pm & 0.0002 & 0.0001 & 0.0002 & 0.0001 \\
\hline \% change & --- & -14.52 & -22.30 & -38.33 \\
\hline Muscle & $0.4227 \mathrm{a}$ & $0.3835 \mathrm{~b}$ & $0.3338 \mathrm{c}$ & $0.2748 \mathrm{~d}$ \\
\hline SD \pm & 0.0003 & 0.0001 & 0.0002 & 0.0002 \\
\hline \% change & --- & -13.90 & -22.93 & -44.16 \\
\hline Liver & $0.5033 \mathrm{a}$ & $0.4960 \mathrm{~b}$ & $0.2443 \mathrm{e}$ & -24.54 \\
\hline SD \pm & 0.0002 & 0.0003 & $0.4128 \mathrm{c}$ & $0.3765 \mathrm{~d}$ \\
\hline \% change & --- & -7.35 & -0001 & 0.0002 \\
\hline
\end{tabular}

Data are means \pm SD $(n=6)$ for an organ in a row followed by the same letter are not significantly different $(p<0.05)$ from each other according to Duncan's multiple range test.

Table 2: Sodium ion content ( $\mu \mathrm{g} / \mathrm{g}$ wet wt. of the organ) in organ of fish, Cyprinus carpio exposure to lethal concentration (7.5 $\mu \mathrm{l} / \mathrm{l})$ of quinalphos.

\begin{tabular}{|l|l|l|l|l|}
\hline \multirow{2}{*}{ Tissue } & \multirow{2}{*}{ Control } & \multicolumn{4}{|l|}{ Lethal Exposure Period in Days } & Day 3 \\
\cline { 3 - 5 } & & Day 1 & Day 2 & $0.8152 \mathrm{~d}$ \\
\hline Gill & $0.9937 \mathrm{a}$ & $0.9025 \mathrm{~b}$ & $0.8737 \mathrm{c}$ & 0.0003 \\
\hline SD \pm & 0.0002 & 0.0002 & 0.0003 & -16.34 \\
\hline \% change & --- & -8.05 & -13.56 & $0.7430 \mathrm{e}$ \\
\hline Muscle & $1.0747 \mathrm{a}$ & $0.9872 \mathrm{~b}$ & $0.9033 \mathrm{c}$ & 0.0003 \\
\hline SD \pm & 0.0002 & 0.0003 & 0.0002 & -18.45 \\
\hline \% change & --- & -8.07 & -15.89 & 0.0002 \\
\hline Liver & $0.8837 \mathrm{a}$ & $0.8027 \mathrm{~b}$ & $0.7655 \mathrm{c}$ & -18.48 \\
\hline SD \pm & 0.0002 & 0.0002 & 0.0002 & $0.7121 \mathrm{~d}$ \\
\hline \% change & --- & -9.16 & -13.37 & 0.0004 \\
\hline
\end{tabular}

Data are means \pm SD $(n=6)$ for an organ in a row followed by the same letter are not significantly different $(p<0.05)$ from each other according to Duncan's multiple range test.

Table 3: Potassium ion content ( $\mu \mathrm{g} / \mathrm{g}$ wet wt of the organ) in organ of fish, Cyprinus carpio exposure to lethal concentration (7.5 $\mu \mathrm{l} / \mathrm{l})$ of quinalphos.

\begin{tabular}{|l|l|l|l|l|}
\hline \multirow{2}{*}{ Tissue } & \multirow{2}{*}{ Control } & \multicolumn{4}{l|}{ Lethal Exposure Period in Days } \\
\cline { 3 - 5 } & & Day 1 & Day 2 & Day 3 \\
\hline Gill & $0.8627 \mathrm{a}$ & $0.7932 \mathrm{~b}$ & $0.7457 \mathrm{c}$ & $0.7217 \mathrm{~d}$ \\
\hline SD \pm & 0.0002 & 0.0003 & 0.0003 & 0.0003 \\
\hline \% change & --- & -8.05 & -13.56 & -16.34 \\
\hline Muscle & $1.2232 \mathrm{a}$ & $1.0538 \mathrm{~b}$ & $0.9425 \mathrm{c}$ & $0.9228 \mathrm{~d}$ \\
\hline SD \pm & 0.0003 & 0.0002 & 0.0003 & $0.7035 \mathrm{e}$ \\
\hline \% change & --- & -13.90 & -22.93 & -18.45 \\
\hline Liver & $0.9128 \mathrm{a}$ & $0.8835 \mathrm{~b}$ & 0.0002 & -24.54 \\
\hline SD \pm & 0.0002 & 0.0003 & $0.8663 \mathrm{c}$ & $0.7968 \mathrm{~d}$ \\
\hline \% change & --- & -3.20 & 0.0002 & -27.66 \\
\hline
\end{tabular}

Data are means $\pm \mathrm{SD}(n=6)$ for an organ in a row followed by the same letter are not significantly different $(p<0.05)$ from each other according to Duncan's multiple range test.

Table 4: Calcium ion content ( $\mu \mathrm{g} / \mathrm{g}$ wet wt. of the organ) in organ of fish, Cyprinus carpio exposure to lethal concentration (7.5 $\mu \mathrm{l} / \mathrm{l})$ of quinalphos. 


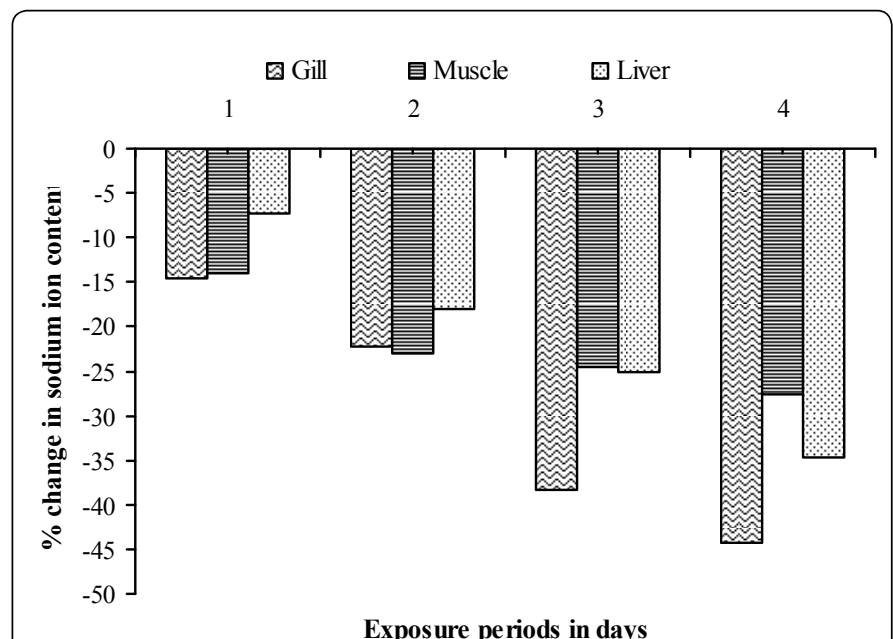

Figure 1: Sodium ion content in organ of fish, Cyprinus carpio exposure to lethal concentration $(7.5 \mu \mathrm{l} / \mathrm{l})$ of quinalphos.

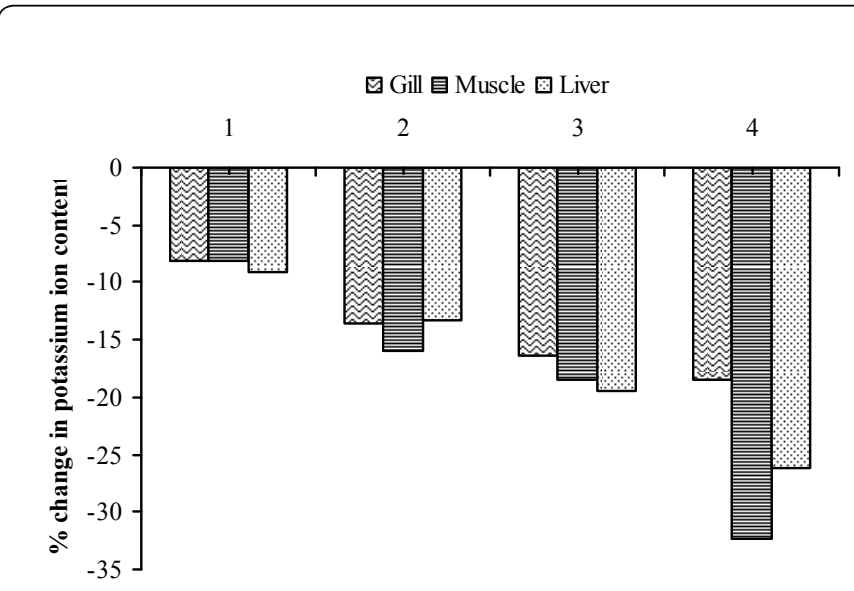

Exposure periods in days

Figure 2: Potassium ion content in organ of fish, Cyprinus carpio exposure to lethal concentration $(7.5 \mu \mathrm{l} / \mathrm{l})$ of quinalphos.

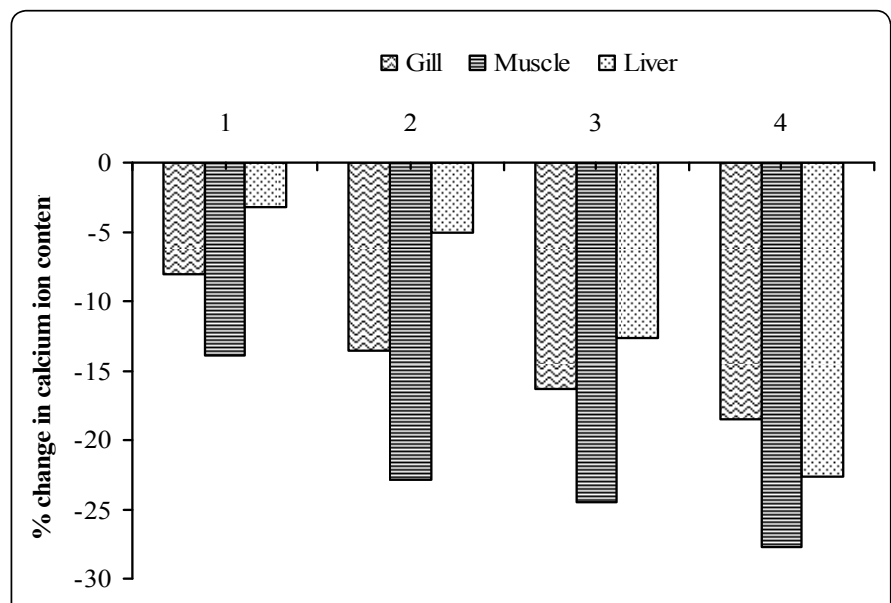

Exposure periods in days

Figure 3: Calcium ion content in organ of fish, Cyprinus carpio exposure to lethal concentration $(7.5 \mu \mathrm{l} / \mathrm{l})$ of quinalphos. ventilatory, activity, particularly if the environment factors affect respiratory gas exchanges [10]. The fluctuated response in respiration may be attributed to reduction in gill permeability causing a drop in oxygen consumption for which the fish compensates by increasing the ventilation volume observed by Kalavathy et al. [11]. Several authors suggested that the gills are the major respiratory organs and all metabolic pathways depend upon the efficiency of the gill for their energy supply and any damage to this vital organ causes a chain of destructive events, which ultimately lead to respiratory distress $[12,13]$. According to Natarajan et al. [14] the decrease in oxygen consumption uptake from pesticide water is mainly due to shrinkage of the respiratory epithelium since there is swelling of the secondary lamellar tips. The gill opercular movements increased initially to support enhanced physiological activities in stressful habitat and later decrease, possibly due to mucus accumulation on gills. This been reported by David et al. [15] and Devaprakasa Raju, [16]. The coagulation of mucus on the gill caused demolition of various important processes such as gas exchange, nitrogen excretion, salt balance and circulation of blood [17]. Decrease in oxygen up take efficiently was noted in rainbow trout exposed to fenvalerate and cypermetrin by Bradbury et al. [18]. Similar situation was observed by in Cirrhinus mrigal and Labeo rohita, exposed to fenvalerate [2]. The decrease in oxygen consumption appears to be a protective measure to ensure that there is low intake of the toxic substance.

In fishes, gills form major site for ion transport and osmotic water movements, hence also for pesticide entry. They are in constant touch with the water. This affects the permeability characteristics and osmoregulatory function of the gills there by resulting in the decrease of these ions in gill tissue upon exposure to quinalphos. An appraisal of result in the present study suggests that the sodium, potassium and calcium ions in gill, muscle and liver exposed to lethal concentration of quinalphos indicates change in the permeable properties of the cell membrane of these organs and of deranged $\mathrm{Na}^{+}, \mathrm{K}^{+}$and $\mathrm{Ca}^{2+}$ ionic pump due to the probable consequences of tissue damage [19]. It is known that $\mathrm{Na}^{+}$pump which regulates the ionic content of the tissues. The level of $\mathrm{Na}^{+}$signifies the importance of tissue in the mobilization of the water transport, since sodium content in the membrane facilitates the water movement among the tissues [20]. In this investigation, it is evident that $\mathrm{Na}^{+}$loss is higher in the case of gill indicating the derangement in $\mathrm{Na}^{+}$transport and rupture in the respiratory epithelium of gill tissue [21].

It is known that any remarkable decrease in $\mathrm{K}^{+}$ion level might be accompanied by serious disturbance in muscular irritability, myocardial function and respiration [22]. The creases in $\mathrm{K}^{+}$ion content in the tissues of Cyprinus carpio exposed to quinalphos might attribute to the derangement in whole animal oxygen consumption and ionic content at tissue levels as observed in the present investigation. The decrease in $\mathrm{Ca}^{2+}$ ion level indicates increased decalcification. $\mathrm{Ca}^{2+}$ is concerned with neuromuscular excitability, cell membrane permeability and regulation of protein binding capacity [23]. In the present study, the restlessness in fish during organophosphate stress corresponds to structural change in mitochondrial integrity. Since mitochondria acts as "sink" for intracellular $\mathrm{Ca}^{2+}$ and as principle store house of $\mathrm{Ca}^{2+}$, it appears that decrease $\mathrm{Ca}^{2+}$ may be attributed to the disturbance in mitochondrial integrity and subsequent respiratory distress [24].

Decrease in $\mathrm{Ca}^{2+}$ content may also be due to deranged neural transmission and acetylcholinesterase activity during quinalphos toxicity. Since it was reported that the inhibition of acetylcholinesterase activity and subsequent accumulation of acetylcholine at the nerve 
Citation: Chebbi SG, David M (2010) Quinalphos Induced Alterations in the Levels of lons and Whole Animal Oxygen Consumption of Freshwater Fish, Cyprinus Carpio (Linnaeus, 1758). J Veterinar Sci Technol 1:102. doi:10.4172/2157-7579.1000102

Page 4 of 4

ending accounts for decrease $\mathrm{Ca}^{2+}$ content [25]. Hoar [26] suggested that the levels of amino acids and metabolites like pyruvate and lactate will be increase under stress conditions to compensate the loss of inorganic ions. In support to this, amino acids and lactate were found increased in tissues of Catla catla exposed to endosulfan [10].

Thus, is quite apparent that the fish, Cyprinus carpio under quinalphos stress seldom under goes total abolition of functional regulation of the ionic transport and water permeability system and the imbalance in osmoregulation is compensated in harmonic manner through the production of biochemically changed components like amino acids which go to rescue and compensate the imbalance ionic composition. Thus, an intrinsic osmoregulatory ability of fish is viewed in a nutshell but clear understanding on the basis of water permeability versus $\mathrm{Na}^{+}$transport and the position of $\mathrm{Ca}^{2+}$ in water transport mechanisms still awaits direct analysis and will certainly throw light on the principles behind this.

\section{Acknowledgement}

I am thankful to my teacher Dr. M. David and other teaching and non teaching staff of Karnatak Science College, and I also thankful my parents Mr. G. J. Chebbi and Mrs. M. G. Chebbi and my wife Mrs. V. S. Chebbi and my daughter Miss. S.S. Chebbi for their kind support during my research tenure.

\section{References}

1. Pimentel D, Levitan $L$ (1986) Pesticides amount applied and amounts reaching pests. Bioscience 36: 86-91.

2. Mushigeri SB, David M (2002) Assessment of fenvalerate toxicity by the changes in oxygen consumption and ammonia excretion in the fresh water fish Cirrhinus mrigal (Hamilton). Ecotoxicology and Environmental Monitoring 12: 64-65.

3. Narasimhan PVSL, Swami KS, Chetty CS (1983) Polarization of selected oxidoreducatase in the axoplams of sheep medulla oblongata during electro induced intercellular transport. Indian journal Comparative Animal Physiology 1: 14-17.

4. APHA (2005) Standard Methods for the Examination of Water and Wastewater. 21st ed., American Public Health Association (APHA), Washington DC, USA.

5. Finney DJ (1971) Probit analysis 3rd (Ed.) Cambridge University Press London $333 \mathrm{pp}$.

6. Welsh JH, Smith RI (1953) Laboratory exercises in invertebrate physiology. Burgess Publishing Company, Minneapolis, USA.

7. Saroja KS (1959) Oxygen consumption in relation to body size and temperature in the earthworm, Megascolex marutii when kept submerged under water. Proceedings of Indian Academic of Science 49: 183-193.

8. Dall W (1967) Hypo-osmoregulation in crustacean. Comp Biochem Physiol 21: 653-678.

\section{Duncan DM (1955) Multiple range and multiple tests. Biometrics}

10. Shivakumar R (2004) Endosulfan induced metabolic alternation in the freshwater fish, Catla catla (Hamilton). Ph.D. Thesis of Karnatak University, Dharwad, Karnataka, India.

11. Kalavathy K, Sivakumar AA, Chandran R (2001) Toxic effects of the pesticide dimethoate on the fish, Sarotherodon mossambicus. Journal Ecological Research Biology 2: 27-32.

12. Radhaiah V (1987) Studies on the toxic impact of pyrethroid insecticide fenvalerate on the some metabolic aspect and histopathology of fresh water teleost, Tilapia mossambica. Ph.D. Thesis, S.V. University, Tirupati, Andra Pradesh, India.

13. Magare SR, Patil HT (2000) Effect of pesticides on oxygen consumption, red blood cell count and metabolites of a fish, Puntius ticto. Environ Ecol 18: 891-894.

14. Natarajan GM, Sundararajulu G, Sivagamasundari S, Subramanian S (1983) Effect of sublethal concentration metasystox on the circadian rhythm of bimodal oxygen uptake in Channa straitus. Current Science 52: 675-678.

15. David M, Mushigeri SB, Philip GH (2002) Toxicity of fenvalerate to the fresh water fish, Labeo rohita. Geobios 29: 25-29.

16. Raju DB (2000) Fenvalerate induced changes in the protein metabolism of Freshwater fish, Tilapia mossambica. Ph.D. Thesis, S.K. University, Anatapur, India.

17. Skidmore JF (1964) Toxicity of zinc compounds to aquatic animals with special reference to fish. Quart. Rev Bio 39: 227-248.

18. Bradbury SP, Coats JR, Mc Kim JM (1986) Toxicokinetics of fenvalerate in rainbow trout Salmo gairdneri. Environmental Toxicology and Chemistry 5: 567-576.

19. Leone J, Ochs S (1978) Anoxic block and recovery of exoplasmic transport and electrical excitability of nerve. Journal Neurobiology 9: 229-245.

20. Symonik DM, Coats JR, Bradbury SP, Atchison GJ, Clark JM (1989) Effect of Fenvalerate on metabolic ion dynamics in the fathered Minnow (Pimpephales promelas) and bluegill (Lepomis maerocliurs). Bull Environ Contam Toxicol 42: 821-828.

21. David M, Mushigeri SB, Philip GH (2003) Alternation in the levels of freshwater fish, Labeo rohita exposed to fenvalerate. Pollution Research. 22:359-363.

22. Kabeer Al, Jaganath RKS, Rao RKV (1981) Effect of malathion exposure on some physical parameters of whole blood and on tissue cations of teleost, Tilapia mossambica. Journal of Biological Science. 3: 523-526.

23. Walser M (1960) Ion association; the effect of multivalent ions on the protein bond and complexed calcium in serum. Comparative Biochemistry and Physiology. 55: $245-250$.

24. Malla Reddy $P$ (1992) Changes in levels of respiration and ions in the tissues of freshwater fish, Labeo rohita under cypermetrin stress. Chemosphere. 25:843857.

25. Bandopadhyay R (1982) Inhibition of acetylcholinesterase by permethrin and its reversion by acetylthiocholine. Indian Journal Experimental Biology 20:488-491.

26. Hoar WS (1976) General and comparative physiology. 2nd edn. Prentice half of private India Ltd. New Delhi, India.26pp. 